Yayın Gelis Tarihi: $\quad 29.12 .2016$

Yayın Kabul Tarihi: 05.07.2017

Online Yayın Tarihi: 04.12.2017
Dokuz Eylül Üniversitesi

İktisadi ve İdari Bilimler Fakültesi Dergisi

Cilt:32, Sayı:2, Yıl:2017, ss. 263-288

\title{
Kamu Politikalarında Yasalaştırma Süreci: 6360 Sayılı Yasa Üzerinden Bir İnceleme Veysel ERAT ${ }^{1}$

\author{
Yakup ÖZKAYA ${ }^{2}$
}

\begin{abstract}
$\ddot{O} z$
6360 sayılı Kanun'un yerel yönetimlerde neden olduğu değişimler ve olası etkileri idari, mali, siyasi ve yasal boyutlarıyla geniş bir çerçevede incelenmiştir. Bu çalışmanın diğer çalışmalardan farklı olan yönü, 6360 sayıl yasanın kamu politikasının kavramsal çerçevesiyle ele alınmasıdır. Çalışmada yasalaştırma aşamasında öne sürülen görüşlerin, TBMM tutanaklarının, komisyon raporlarının ve soru önergelerinin tasnif ve tahlil edilmesi hedeflenmektedir. Bu bağlamda çalışmanın iki temel çıktısı olacaktır. Öncelikle yasanın bu yönüyle ele alınması ileride tam olarak uygulandığında geçmişe dönük karşılaştırma yapılmasına olanak tanıyacaktır. Ikinci olarak, Türkiye'de giderek gelişen kamu politikası yazınında göz ardı edilen yasalaştırma aşamasının incelenmesiyle disipline katkı sunulacaktır.
\end{abstract}

Anahtar Kelimeler: 6360 sayılı yasa, Kamu politikası, Yasalaştırma.

JEL Sinıflandırma Kodları: D72, D79, L38.

\section{The Enactment Process in Public Policies: An Examination on the Law No. 6360}

\begin{abstract}
The changes on local administrations brought by The Law No. 6360 and its possible effects have been examined in a wide scope with administrative, financial, political and legal dimensions. What this study differs from other studies is that it handles The Law No. 6360 with conceptual framework of public policy. This study aims to classify and assay the proposed arguments, the minutes of Turkish Grand National Assembly, commission reports and parliamentary questions in the enactment stage. There will be two outcomes in this context. At first, handling this law with this way will enable the retrospective comparison when it will be fully applied in the future. Secondly, the contributions to the discipline will be put forth by examining the enactment stage which is ignored in the developing public policy literature in Turkey
\end{abstract}

Keywords: The Law No.6360, Public policies, Enactment.

JEL Classification Codes: D72, D79, L38.

1 Yrd. Doç. Dr., Bitlis Eren Üniversitesi, İktisadi ve İdari Bilimler Fakültesi, Kamu Yönetimi Bölümü, veyselerat@hotmail.com

${ }^{2}$ Araş.Gör., Dokuz Eylül Üniversitesi, İktisadi ve İdari Bilimler Fakültesi, Kamu Yönetimi, Bölümü, yakup.ozkaya@deu.edu.tr 


\section{GíRİş}

\section{V.ERAT -Y.ÖZKAYA}

Kamu politikalarını oluşturma, genellikle resmi bir düzenlemeye dayansa da yasalaştırma aşaması tüm kamu politikalarında varlık kazanan bir aşama değildir. Kamu politikalarında yasalaştırma, çoğunlukla politikaların formüle edilmesi ve karar verme aşamasıyla birlikte işleyen bir aşamadır. Bu nedenle literatürde karar verme ve politika oluşturma incelemeleri daha fazladır. Ancak bu yasalaştırma sürecinin tek başına ele alınamayacağı anlamına gelmemelidir. Çünkü politika aktörleri yalnızca politikayı formüle edenler ya da karar vericilerden oluşmamaktır. Özellikle formüle edilen politikanın yasalaştırma aşamasında sivil toplum örgütleri, meclis içindeki ve dişındaki siyasal partiler ile bir dizi etken bu sürece dâhil olmaktadır. Hatta son yıllarda bilimsel verilere ve rasyonel seçime dayalı olarak belirlenen politikaların postmodern merkezli eleştirilere konu olması, politikaların halk nezdinde kabul görmesi ve siyasal sitemin meşruiyetinin devamları açısından müzakereci yaklaşımların önünü açmıştır.

Yerel politikalar müzakere ve katılımın en fazla işletildiği politikalardır. Sadece oy vererek kişisel çıkarlara dayanan bir demokratik yapıdan halen söz edilse de, bu düşüncenin yerini toplumsal çıkarların sağlandığı müzakereci-uzlaşmacı bir demokrasi anlayışına bırakması genel kabul görmektedir. Böylesi bir anlayış vatandaşların karar verme sürecinde etkisini de artıracaktır. Toplumsal çıkarlar, kamu-sivil-özel işbirliğini sağlayarak demokratik kamu yönetişimi felsefesiyle hareket edilmesini mümkün kılacaktır. Burada yurttaşlar, yerelde kendileriyle ilgili çeşitli modelleri olan oylama sistemleriyle politikaları kabul ya da ret ederek yasama sürecine dâhil olmaktadırlar. Müzakereci demokrasi araçlarının yeterince gelişmediği temsili demokrasilerde ise, yasalaştırma sürecinin nasıl işlediği sorusu, çeşitli siyasal partiler aracılığı ile parlamentoda temsil edilen yurttaşların yasama sürecine etkileri, demokratik gelişim düzeyinin anlaşılması açısından önemli bir ölçüttür.

Türkiye'nin genel olarak yerel yönetimler politikasını ve özel olarak yerelde oluşturulan ve uygulanan alt politika alanlarını etkileyen 6360 sayı1ı On Dört İlde Büyükşsehir Belediyesi ve Yirmi Yedi İlçe Kurulması ile Bazı Kanun ve Kanun 
Hükmünde Kararnamelerde Değişiklik Yapılmasına Dair Kanun ${ }^{3}$, temelde iki önemli değişiklik getirmiştir. 6360 sayılı yasa on dört ili büyükşehir statüsüne alarak on altı olan büyükşehir sayısını otuza çıkarmıştır. Bunun yanı sıra İstanbul ve Kocaeli için uygulanan il ve belediye sınırlarının aynı olma özelliğini diğer büyükşehir belediyeleri için de getirmiştir. Çalışmanın sorunsalı ve tartışmaların yürütüleceği politika sürecinde yasalaştırma zemini açısından bu değişikliklerin iki önemli çıktısı bulunmaktadır. Öncelikle yeni yasayla nüfusun yüzde 83’ü (Türkiye Belediyeler Birliği, 2014) büyükşehir sınırları içinde yaşamaya başlamıştır. Diğer yandan kentsel alanlarda yaşayan halka hizmet sunumu için politika üretimi ve uygulanmasında büyükşehir belediyelerinin eli güçlendirilmiştir. Bu bağlamda 6360 sayılı yasa Türkiye'de kamu politikalarında yasalaştırma sürecinin nasıl işlediğini anlamak açısından önemli bir inceleme nesnesidir.

Çalışmanın ana hedefi 6360 sayılı yasa gibi neredeyse ülkenin tamamını etkileyen bir politikanın yasalaştırma sürecinin nasıl işlediğini ve katılım mekanizmalarının işlerliğini anlamaya çalışmaktır. Çalışmada 6360 sayılı yasanın gündeme gelme aşamasından yasalaşıncaya kadar geçen süre analiz edilecektir. $\mathrm{Bu}$ bağlamda çalışma üç ana boyutta tasarlanmıştır. İlk olarak kamu politika süreci ve yasalaştırma aşaması ile ilgili bilgi verilecek, daha sonra 6360 sayılı yasa üzerinde genel bir değerlendirme yapılacak ve son bölümde yasalaştırma süreci incelenecektir. Çalışma literatür taraması ve arşiv araştırmasına dayanmaktadır. İlgili yasa 24. dönem, 2. yasama yılı gündeme geldiği için bu yıla ait 132 birleşim; tasarının yasalaştığı 3. yasama yılına ait 21 birleşim TBMM tutanaklarından tahlil edilmiştir. Ayrıca tasarının sevk edildiği İçişleri Komisyonu'na ait 9, İçişleri Alt Komisyonu'na ait 1 tutanaktan kaynak olarak faydalanılmıştır. Son olarak bu süre içindeki medyada çıkan haberlere ve görüşlere bakılmıştır. Çalışmanın ileride konu ile ilgili yapılacak çalışmalara kaynaklık etmesi ve karşılaştırma olanağı tanıması

${ }^{3}$ 14.3.2013 tarih ve 6447 sayılı Kanunun 1. maddesiyle, 12.11.2012 tarih ev 6360 sayılı Kanunun başlı̆̆ında yer alan "On Üç" ibaresi "On Dört" olarak, "Yirmi Altı" ibaresi "Yirmi Yedi" olarak değiştirilmiş ve 1. maddesinin birinci fikrasın "Ordu" ibaresi eklenmiştir. 


\section{V.ERAT -Y.ÖZKAYA}

beklenmekte, ayrıca kamu politikası yazınında göz ardı edilen yasalaştırma aşamasının incelenmesiyle disipline katkı sunması hedeflenmektedir.

\section{POLITIKKA SÜRECI VE YASALAŞTIRMA}

Devletin yasalara dayanarak otoritesinin bulunduğu konularda kamu görevlisi ya da kamu kurumu aracıllğı ile yapmış olduğu eylem ve işlemler şeklinde tanımlanan kamu politikaları (Akdoğan, 2011, s. 77), belirli aşamalardan oluşmakta ve genellikle döngüsel bir süreç içinde işlemektedir (Yıldız ve Sobacı, 2013, s. 24). Bu anlamıyla süreç ile politik sistem içinde meydana gelen aktiviteler kastedilmekte ve politika süreci politikaların nasıl yapıldığı üzerine odaklanmaktadır (Dye, 2008, s. 56). Aşamaları açısından politika sürecini modelleme fikri ilk olarak Lasswell tarafından ortaya atılmıştır (Jann ve Wegrich, 2007, s. 43). Ancak Lasswell'den sonra konu üzerinde çalışanlar kamu politikalarının birbirinden farklı olması, her kamusal sorunun aynı yöntemle çözülmemesi, süreç içinde öne çıkan aktörlerin değişebilir olması gibi nedenlerle kamu politika sürecinde öngörülen aşamalarda farklı yaklaşımlar önermişlerdir.

Tablo 1: Kamu Politikası Süreci için Bazı Yaklaşımlar

\begin{tabular}{|c|c|c|c|}
\hline $\begin{array}{l}\text { Lasswell } \\
\text { (1971) }\end{array}$ & Dye (1987, s. 14) & Parsons (2001, s. 77) & $\begin{array}{r}\text { Jenkins } \\
(1978, \text { s. 36) }\end{array}$ \\
\hline Haber Alma & Problemi Tanıma & Problemi Tanımlama & Başlatma \\
\hline Tanitma & Gündeme Getirme & Çözümleri Tanımlama & Bilgi \\
\hline Formüle Etme & Formüle Etme & Seçenekleri Değerlendirme & Düşünme \\
\hline Başlatma & Yasalaştırma & Seçim Yapma & Karar verme \\
\hline Uygulama & Uygulama & Uygulama & Uygulama \\
\hline Sonlandırma & Değerlendirme & Değerlendirme & Sonlandirma \\
\hline \multicolumn{4}{|l|}{ Değerlendirme } \\
\hline $\begin{array}{l}\text { Anderson } \\
(1994, \text { s. 38) }\end{array}$ & $\begin{array}{c}\text { Stewart, } \\
\text { Hedge\&Lester }\end{array}$ & $\begin{array}{l}\text { Howlett\&Ramesh } \\
\text { (1995) }\end{array}$ & $\begin{array}{l}\text { Jann\&Wegrich } \\
\text { (2007) }\end{array}$ \\
\hline
\end{tabular}




\begin{tabular}{|l|l|l|l|} 
& (2008) & & \\
\hline $\begin{array}{l}\text { Tanıma } \\
\text { Gündem B. }\end{array}$ & Gündem Belirleme & Gündem Belirleme & $\begin{array}{l}\text { Gündem } \\
\text { Belirleme }\end{array}$ \\
\hline Formüle Etme & Formüle Etme & Formüle Etme & $\begin{array}{l}\text { Formüle Etme } \\
\text { ve Karar Verme }\end{array}$ \\
\hline Yasalaştırma & Uygulama & Karar Verme & Uygulama \\
\hline Uygulama & Değerlendirme & Uygulama & $\begin{array}{l}\text { Değerlendirme } \\
\text { ve Sonlandırma }\end{array}$ \\
\hline Değerlendirme & $\begin{array}{l}\text { Sonlandı̆iștirme } \\
\text { Ve }\end{array}$ & Değerlendirme & \\
\hline
\end{tabular}

Kaynak: (Arap ve Erat, 2015, s. 79).

$\mathrm{Bu}$ yaklaşımlarda farklılık bulunsa da genel olarak kamu politika süreci, yönetimin tanımış olduğu bir sorun için çözüm üreterek, yasal zeminini hazırlayıp politikayı uygulaması ve bu süreçte değerlendirmesi şeklinde tanımlanabilir. Kamu politikalarını zamansal olarak aşamalara ayırıp modellemenin birçok yararı olsa da temelinde karmaşık olan politikaları basitleştirerek daha anlaşılır kılması yatmaktadır (Kapt1, 2016, s. 113; Dye, 1987, s. 14; Howlett ve Ramesh, 1995, s. 9). Sabatier (2007, s. 6) süreç modelin, 1970'lerde ve 1980'lerin başında, kamu politikalarının anlaşılmasında yararlı olduğunu ifade etmekte, ancak 1980'lerin sonunda konu üzerine çalışan bazı yazarlarca eleştirildiğini belirtmektedir. Nitekim politikalar her zaman süreç modelin öngördüğü şekilde tek yönlü ve sıraları aşamalar takip edilerek yapılmaz. Örneğin bazı politikalar gündemin üst sıralarına girmeksizin ilerler ve birçok durumda politikalar değerlendirilmez. Birçok eleştiri getirilse de bu model, sosyal bilimcilere oldukça yardımcı olmuştur (Birkland, 2005, s. 188).

Günümüzde hala karar verme ve uygulama başta olmak üzere kamu politikas1 süreci aşamaları üzerinde çalışmalar yer almaktadır. Bu çalışmada farklı olarak daha az çalışılan yasalaştırma aşaması üzerinde durulacaktır. Dikkat edilirse, Tablo 1 incelendiğinde birçok yazar yasalaştırmayı süreç içinde bir aşama olarak görmemektedir. Bunun önemli bir nedeni sorun karşısında geliştirilen çözüme 
V.ERAT -Y.ÖZKAYA
karar verildiğinde yasalaştırmanın bunun tekniğe ilişkin resmi yönünü
oluşturmasıdır.

Karar verme aşamasından sonra gelen yasalaştırma ile kastedilen kanun, düzenleme ya da başka bir resmi karar ile problemi çözmek için eyleme geçme aşamasına geçilmesidir (Birkland, 2011, s. 26). Kamu politikasının en önemli yazılı programı olan yasa, politikanın şekillendirilmesinde önemli bir adımdır (Çevik ve Demirci, 2012, s. 58). Basit fakat zor bir süreç olarak tanımlanan bu aşamada politikacıların kendi çıkarlarını koruma saikıyla hareket etmeleri, güçlerini arttırmayı amaçlamaları ve genellikle anlam odaklı hareket etmeyi sonuç odaklı hareket etmeye tercih etmeleri çoğu zaman çatışmalara zemin hazırlamaktadır (Akgül ve Kapt1, 2010, s. 82-83). Politikacıların sapma gösterecekleri ideolojik sapmalar ve kazanç arayıcılar şeklinde iki temel husus bulunmaktadır. Birincisine göre, politikacıların hareket tarzını kendi ideolojileri ya da seçmenlerinin ideolojisi belirlemektedir. Bununla çelişen kamu yararına politikacılar olumlu bakmazlar ve kendi ideolojik gündemlerini savunurlar. İkincisinde ise genelin yerine kendi ya da bir takım grubun menfaatini isteyerek hareket ederler. Ayrıca genel olarak yasalaştırma sürecinde politikacılar taraf tutma, kredi sağlama ve reklam yapma şeklinde tutular takınırlar (Kaptı, 2013, s. 35).

Çıkarılması genellikle yasama organının yetkisinde olan bir faaliyet olsa da yasalaştırma aşamasında başta siyasal partiler ve sivil toplum örgütleri olmak üzere kamu kurum ve kuruluşlarının yanı sıra, yargı organları, diğer ilgili gruplar ve kamunun kendisi dâhil birçok aktör bulunmaktadır. Ayrıca her ülkenin demokratiklik düzeyi, katılım mekanizmalarının işlerliği ve hükümet sistemi gibi birçok olgu yasalaştırma sürecine etki etmektedir.

\section{6360 SAYILI YASA VE YEREL YÖNETIMLERIN DEĞISŞEN}

\section{YAPISI}

AK Parti hükümetinin küreselleşmenin yönetim yaklaşımında değişime neden olduğu ve bu değişimin etkin, etkili, vatandaş odaklı, hesap verebilen katılımcı ve şeffaf yönetim ilkelerini ön plana çıkardığından hareketle 8 Ekim 2012'de Meclise 
sunduğu (Gül, 2013: 31) ve ilk mahalli idareler seçimlerinde yürürlüğe giren 6360 sayılı yasa sadece büyükşehir belediyelerinin sayısında bir artış sağlamamış aynı zamanda görev ve sorumluluk bakımından çarpıcı ve radikal değişiklikler getirmiştir. Dolayısıyla yasanın çok boyutlu tahlili, günümüzdeki şeklini alması ve Türk idari yapısında ciddi değişiklikler yaratması yönüyle oldukça önemlidir. 1982 Anayasası sonrasında yasanın nasıl bir siyasi süzgeçten geçtiğini ve bu süreçte hangi yasal düzenlemelerin 6360 sayılı yasaya zemin hazırladığını söyleyebilmemiz için ise tarihi süreci yakından incelememiz gerekmektedir.

1982 Anayasası'nın 127. maddesi 3. fikrasında “Kanun, büyük yerleşim merkezleri için özel yönetim biçimleri getirebilir" hükmü ile büyükşehir belediyelerine anayasal dayanak sağlanmıştır. Bu hükme dayanılarak 1984 yılında çıkarılan 2972 sayılı "Mahalli idareler ve ile Mahalle Muhtarlıkları ve Ihtiyar Heyetleri seçimi Hakkında Kanun” ve 195 Sayılı KHK uyarınca Türkiye'nin üç büyük yerleşimi olan İstanbul, İzmir ve Ankara'da büyükşehir belediyeleri kurulmuştur. Bu üç kenti aynı yıl çıarılan 3030 sayılı “Büyükşehir Belediyelerinin Yönetimi Hakkında Kanun Hükmünde Kararnamenin Değiştirilerek Kabulü Hakkında Kanun” "ile büyükşehir ve ilçe belediyelerinin statüleri netleşmiştir.

3030 Say1lı kanun ile Türkiye'de yerel yönetimler literatürüne "Büyükşehir Belediyesi" ve "İlçe Belediyesi” olarak iki yeni idari birim girmiştir (Parlak ve Ökmen, 2015, s. 272). 2004 tarihli ve 5216 sayılı "Büyükşehir Belediyesi Kanunu" kabul edilene kadar 3030 sayılı kanun yürürlükte kalmıştır. Bu yıla kadar sırasıyla Adana (1986), Bursa, Gaziantep ve Konya (1987), Kayseri (1988), Antalya, Diyarbakır, Erzurum, Eskişehir, Kocaeli, Mersin ve Samsun (1993), Adapazarı (2000) büyükşehir belediyeleri kurulmuştur. 5216 sayılı Büyükşehir Belediyesi Kanunu, büyükşehir belediyelerinin yetkilerini artırarak, fonksiyonlarını değiştirmiştir. Son olarak, 6360 sayılı yasa ile 2012 yılında, büyükşehir belediyelerinin sayısı 16'dan 29'a yükseltilmiştir (Aydın, Balıkesir, Denizli, Tekirdağ, Hatay, Manisa, Kahramanmaraş, Malatya, Mardin, Muğla, Trabzon, Şanlıurfa, Van). Bunlara 2013 yılında 6447 sayılı yasayla Ordu da eklenmiştir. Böylelikle sınırları il sınırı olan büyükşehir belediye sayısı 30'a yükselmiştir. 


\section{V.ERAT -Y.ÖZKAYA}

Dikkat edilirse Türkiye'de uzun tarihi geçmişi olan bir büyükşehir belediye yapılanmasından söz etmek mümkün değildir.

1982-2012 yılları arasındaki yerel yönetim mevzuatı ile 2012 yılında yürürlüğe giren 6360 sayılı yasa karşılaştıııldığında, 6360 sayılı yasanın belediye sınırlarını il mülki sınırı haline getirerek tüm ili ve hatta bölgeyi de kapsayan makro politikalara ihtiyaç duyulmasını gerekli kılan koordinasyon ve eşgüdümü daha önemli hale getiren bir yapının doğmasına sebep olduğu görülmektedir. Yasanın diğer önemli göstergesi 1913 tarihli “İdare-i Umumiye-i Vilayet Kanunu Muvakkati” ile kurulmuş ve Türkiye'de il idaresinin yerel yönetim yapılanması yönünü öne çıkaran yaklaşık bir yüzyıllık geçmişe sahip İl Özel İdareleri ve aynı geçmişe sahip 1924 tarihli 442 sayılı Köy Kanunu ile Köy İdareleri 30 büyükşehirde kaldırılmasıdır. Daha açık bir ifadeyle, Türkiye'de tüm ili kapsayan il özel idaresi, belli bir nüfusa sahip yerleşim merkezlerinde ve ilçelerde belediyeler, bu eşiğin altındaki yerleşmelerde ise köy yönetimine dayalı üçlü bir yerel yönetim sistemi vardı. Büyük yerleşim merkezlerindeki belediye sistemi ise, bu genel sisteme ilave bir unsur olarak devreye girmekteydi. Ancak 6360 sayılı yasa ile birlikte üç tip yerel yönetim sistemine dayalı genel sistem ile büyükşehir yönetim sistemi birbirinden tamamen ayrılabileceği düşünülmüştür. Hükümeti buna sevk eden nedenler aşağıda gösterilmiştir: (Arıkboğa, 2015, s. 56);

- Türkiye'deki belediyelerin birçoğunun nüfus bakımından küçük olması (örneğin 2012 yılında yaklaşık 2 bin belediyenin nüfusu beş binden daha azdır. Ayrıca 35 binin üzerinde köy yönetimi yer almaktaydı).

- Planlama ve imar, koordinasyon, bütünleşme, toplumsal eşitlik gibi konularda sorun yaratan kentsel alanlardaki idari parçalanmışlık (Göç ile beraber yeni yerleşmelerin belediye sınırı dışında kalan köylere yapılması, zamanla yeni belediyeler kurulmasına sebep olmakta ve hizmette etkinliğe engel olmaktaydı.).

- Hükümetin yerel hizmetlerin sunumu konusunda merkeziyetçi bir yönetimin daha etkin olacağını varsayması (17 binin üzerinde küçük yerel yönetimi 
kapatarak 30 büyükşehir yönetimi ile yerelde özel bir yönetim anlayış1 benimsenmiştir).

- Kamu hizmetlerinin sunumunda koordinasyon eksikliği, küçük yerel yönetimlerin mali kaynaklarının yetersiz olması, sanayileşme, ulaşım, altyapıüstyapı ve çevre gibi konularda yaşanan sorunların küçük ölçekli mahalli idarelerce çözülme zorluğu (Çelikyay, 2014, s. 11).

Yukarıda da belirtildiği üzere 12 Kasım 2012'de 6360 sayılı “On Üç Illde Büyükşehir Belediyesi ve Yirmi Altı İlçe Kurulması ile Bazı Kanun ve Kanun Hükmünde Kararnamelerde Değişiklik Yapılmasına Dair Kanun” ile "hizmetlerde etkinlik" ve "demokratik katılım" mekanizmalarının etkin bir aracı olan il özel idareleri ve köylerin Büyükșehir yönetimlerinde ilgası, büyükşehir yönetiminde hizmetlerde etkinliğe odaklanıldığı bir yönetim anlayışına geçildiğinin bir göstergesidir. Ancak, yerel yönetimlerin temel felsefesine aykırı böyle bir düzenlemenin ne derece etkin olabileceği tereddüt yaratmaktadır (Toprak, 2014, s. 57). Yasanın getirdiği önemli diğer değişiklikler aşağıda listelenmiştir:

- Büyükşehir belediye sınırları il mülki sınırı olmuştur.

- 13 yeni büyükşehir belediyesi kurulmuştur (Bu sayıya daha sonra Ordu ili de eklenmiştir). Böylelikle büyükşehir belediye sayısı toplam 30 olmuştur.

- $\quad$ Bu illerde yeni ilçeler kurulmuştur (6360 ve 6447 sayılı Kanunlarla 27 yeni ilçe tesis edilmiştir).

- $\mathrm{Bu}$ illere bağlı ilçelerin mülki sınırları içinde yer alan köy ve belde belediyelerinin tüzel kişiliği sona ermiştir. Köyler mahalle olmuş belediyeler ise mahalleleriyle birlikte bağlı bulundukları ilçenin belediyesine katılmışlardır. Ayrıca bu illerin bucak ${ }^{4}$ teşkilatları da kaldırılmıştır.

${ }^{4} 6.12 .2012$ tarihli 6360 Sayılı 6360 sayılı On Dört İlde Büyükşehir Belediyesi ve Yirmi Yedi İlçe Kurulması ile Bazı Kanun ve Kanun Hükmünde Kararnamelerde Değişiklik Yapılmasına Dair Kanun'un 1. Maddesinin altıncı fikrasında Büyükşehirlerde bucak ve bucak teşkilatları kaldırılmıştır. 10.09.2014 tarihli 6552 Sayılı İş Kanunu ile Bazı Kanun ve Kanun Hükmünde Kararnamelerde Değişiklik Yapılması ile Bazı Alacakların Yeniden Yapılandırılmasına Dair Kanun'un 129. Maddesindeki hüküm ile 5747 Sayılı Büyükşehir 


\section{V.ERAT -Y.ÖZKAYA}

- Mülki İdare amirleri olan valilere bağl1, illerde, "Yatırım, İzleme ve Koordinasyon Başkanlığı” kurulmuştur.

"Büyükşehir belediyelerinin bulunduğu illerde kamu kurum ve kuruluşlarının yatırım ve hizmetlerinin etkin olarak yapılması, izlenmesi ve koordinasyonu, acil çağrı, afet ve acil yardım hizmetlerinin koordinasyonu ve yürütülmesi, ilin tanitımı, gerektiğinde merkezi idarenin taşrada yapacă̆ yatırımların yapılmasl ve koordine edilmesi, temsil, tören, ödüllendirme ve protokol hizmetlerinin yürütülmesi, ildeki kamu kurum ve kuruluşlarına rehberlik edilmesi ve bunların denetlenmesini gerçekleştirmek üzere valiye bağlı olarak Yatırım İzleme ve Koordinasyon Başkanliğ kurulmuştur (3152, md.28A)."

Valinin il düzeyinde yatırım kararlarını değerlendirmede merkezi yönetimle bağlantılı "tek" organ olması, müzakere aşamalarının azaltılması ve vesayet yetkisinin güçlenmesi anlamına gelmektedir (Toprak, 2014, s. $57)$.

Yerel ve mülki idare sisteminde temel değişiklikler yaratan 6360 sayılı yasa "optimal ölçek" konusunda olumlu bir gelişme olarak değerlendiren görüşler de bulunmaktadır. Buna göre; Büyükşsehir belediyelerine ayrılan bütçenin artırılması da küçük ve yeterli imkânlara sahip olmayan köy ve küçük belediyelerin aksattığı/yerine getiremediği görevlerini yerine getirebilir. Ancak bunun için devralınan il özel idarelerinin malları ve imkânları etkin bir şekilde yürütülmelidir. Ayrıca genel bütçe vergi gelirlerinden aktarılacak payların da sadece nüfusa göre değil aynı zamanda yüzölçümüne göre verilmesi de olumlu bir yeniliktir (Parlak ve Ökmen, 2015, s. 319).

\section{YASA TASARISI TBMM'YE GELINCEYE KADAR YAPILAN}

\section{TARTIŞMALAR}

6360 sayılı büyükşehir yasası ile ilgili ilk önemli adım, İçişleri Bakanlığı'nın 24 Nisan 2012 tarih ve 11085 sayılı genelgesiyle atılmıştır. Bakanlık genelge ile 27

Belediyesi Sınırları İçerisinde İlçe Kurulması ve Bazı Kanunlarda Değişiklik Yapılması Hakkında Kanun'un 2. maddesi dokuzuncu fikrası değiştirilerek tüm illerde bucaklar kaldırılmıştır. "Kaldırılan bucaklara bağlı belde ve köyler, bucağın bağlı olduğu idari birime bağlanmıştır." Her ne kadar 5442 Sayılı İl İdaresi Kanunu'nun 1. maddesinde halen bucak birimi yer alsa da uygulamada bucak idaresi kamu yönetimi teşkilatlanmasından tamamen kaldırılmıştır. 
ilde belde belediyelerinin, 29 ilde de köylerin yetkilerini valiliklere devretmiştir. Böylece İstanbul ve Kocaeli hariç mevcut büyükşsehir belediyeleri ile büyükşehir statüsünün kurulacağı 13 belediye sınırı içindeki belde belediyeleri; İstanbul ile Kocaeli'nin dâhil olduğu toplam 29 belediyede köyler yetkilerini valinin onayına bağlı olarak kullanacak duruma gelmiştir. Her ne kadar Danıştay bu genelge için sonradan yürütmeyi durdurma kararı alsa da genelgenin getirdiklerini büyükşehir yasasının son aşamasına geldiği yönünde yorumlayan sivil toplum örgütleri yaşanacak değişimi gündemde tartışmaya başlamıştır (YAYED, 2012a; YAYED, 2012b). 27 Mayıs 2011'de dönemin Başbakanı Recep Tayyip Erdoğan, 12 Haziran 2011 seçimleri nedeniyle Muğla'da gerçekleştirdiği mitingde, seçim sonrasında Muğla'nın da içinde bulunduğu 11 ilin büyükşehir statüsüne alınacağını belirtmiştir. Plan bütünlüğünün sağlanması ve illerin tamamında büyükşehir hizmetinin olması için yeni büyükşehir statüsünün İstanbul ve Kocaeli’nde olduğu gibi il sınırını kapsayacağını vurgulamıştır (AK Parti, 2011). Seçimlerden sonra Erdoğan, hükümet programını okurken benzer ifadeler kullanarak, nüfusu 750 bini aşan illerde büyükşehir belediyesi kurulacağını açıklamıştır. Ayrıca yerel yönetimlerin finansman ve hizmet imkânlarının güçlendirileceğini vurgulamış ve merkezi idareden ayrılan bütçe ile yerel yönetimlerin altyapı yatırımlarının destekleneceğini ifade etmiştir (TBMM Tutanak Dergisi (TD), 2011a). Bu tarihten sonra birçok defa büyükşehirler ile ilgili konu TBMM gündemine gelmiştir. Bunların bir kısmı seçim süresince sayılan illere büyükşehir statüsünün kazandırılmasıyla (TBMM TD, 2011b; TBMM TD, 2011c; TBMM TD, 2011d; TBMM TD, 2011e; TBMM TD, 2012a; TBMM TD, 2012b); diğer bir kısmı yeni yasanın muhalefet tarafından öngörülen olası olumsuzlukları ile ilgilidir. Yasalaştırma aşamasında ilgili yasanın içeriği hakkında iktidar partisi dışındaki grupların ne düzeyde bilgi sahibi oldukları ve etki derecelerini tespit edebilmek için bu başlıkta yasanın muhteviyatından haberdar olma düzeylerine ilişkin bir inceleme yapılmıştır. Bu da doğal olarak yasanın ne getirdiğiyle ilgili iktidar ve dışındaki partilerin arasındaki bilgi akışının üzerinde durulmasını gerekli kılmaktadır. 


\section{V.ERAT -Y.ÖZKAYA}

İktidar partisinin içeriğini neredeyse gizlediği tespitinde bulunabileceğimiz yasa tasarıs1 ile ilgili olarak MHP milletvekili Ali Uzunırmak Aydın ili özelinde kaygılarını şu şekilde dile getirmiştir:

“...büyükşehir olma vaadi içerisinde hiçbir şey planlanmamıştır ve Aydın'da hiçbir şey de tartışılmamaktadır. Yarınlarda bir oldubittiyle oradaki insanların hangi ekonomik, sosyal ve güvenlik alanındaki hangi ilçenin, hangi beldenin, hangi mahallenin hangi şartlarda yönetilebilir olmasının mümkün olup olmadı̆̆ını tartışmadan Aydın bir maceraya doğru sürüklenmektedir."

Aydın iline ilişkin çeşitli rakamlar vererek savlarını desteklemeye çalışan Uzunırmak, mevcut durumda ilin tamamına hizmet götürme imkânının olmadığını belirtmiştir (TBMM TD, 2011f). Yakın bir tarihte Van depremi ile ilgili konuşan BDP milletvekili Adil Kurt da Van'ın büyükşehir olmasının mevcut sorunlarını çözmeyeceğini belirtmiştir. Aynı gün söz alan MHP milletvekili Mehmet Erdoğan, meclis gündemine gelecek olan büyükşehir yasasının yerel özerkliğe zemin hazırlayacağı kaygısını parti olarak taşıdıklarını dile getirmiştir (TBMM TD, $2011 \mathrm{~g}$ ). Bunun dışında yasa tasarısı meclis gündemine girmeden önce muhalefet partilerinin İstanbul ve Kocaeli büyükşehir uygulamalarının model alınacağı yeni yasa ile ilgili sözlü olarak dile getirilen görüşler şu şekildedir:

- $\quad$ İl genel meclislerinin devre dışı bırakılmak istendiği (TBMM TD, 2012c),

- Hizmet sunumunda aksaklıkların olacağı, (TBMM TD, 2012d; TBMM TD, 2012e),

- Belde belediyelerinin kaldırılmasının faydalı olmayacağı,

- Uygulamanın halka birtakım yükler getireceği,

- Büyükşehir kurulacak ildeki halka referandumla sunulması (TBMM TD, 2012f).

Buna karşın iktidar partisi, büyükşehir modelinin illeri planlı bir yapıya kavuşturacağ1 ve belediyelerin gelirlerini arttıracağ1 tezine dayanarak hizmet sunumunu daha etkin bir şekilde yerine getireceğini belirtmiştir (TBMM TD, 2011h; TBMM TD, 2012g; TBMM TD, 2012e). 
Mecliste yapılan konuşmaların yanı sıra milletvekilleri yazılı soru önergeleriyle yasanın içeriği ile ilgili bilgi almak istemişlerdir. Diyarbakır milletvekili Altan Tan, Şubat 2012'de, nüfusu 750 bini aşan iller için büyükşehir statüsüne kavuşturulması ile ilgili bir çalışma olup olmadığını, eğer varsa içeriğinin ne olduğuna dair dönemin İçişleri Bakanı İdris Naim Şahin'in cevaplaması üzerine önerge vermiştir (Tan, 2012). Bakanlıktan gelen cevapta yapılan çalışmaların teknik düzeyde ilerlediği belirtilmiş ve kapsamı hakkında bilgi verilmemiştir (İçişleri Bakanlığı, 2012a). Bu tarihten sonra birçok defa CHP ve MHP milletvekilleri tarafindan büyükşehir ile ilgili yapılan çalışmalarla ilgili bilgi alınmak istenmişse de herhangi bir cevap alınamamıştır. Genel olarak yazılı soru önergelerinin kapsamı aşağıdaki gibidir (Akova, 2012; Havutça, 2012; Büyükataman, 2012; Ağbaba, 2012; Oran, 2012; Ören, 2012).

- İstanbul ve Kocaeli büyükşehir modeli diğer büyükşehirler için düşünülmekte midir?

- Büyükşehir uygulamasının olumlu/olumsuz etkileri hakkında halk bilgilendirilecek midir ve referandum yapılmak istenmekte midir?

- TUIKK verilerine göre tasarı nasıl şekillenecektir?

- Tasarı büyükşehir mi bütünşehir olarak mı hazırlanmaktadır, eğer bütünşehir olarak hazırlanıyorsa bunun neden olacağı olumsuzluklar hesaplanmış midir?

- Kapatılacak belediyelerle ilgili makul bir çözüm bulunmuş mudur?

- Büyükşehir yapılacak illerde nüfusu on binin altında olan ilçelerde belediyeler kapatılacak mıdır? Eğer kapatılacaksa buradaki hizmetler nasıl yapılacaktır ve kaymakamlık, adliye diğer kamu kurumları ve çalışanları ile ilgili hükümetin tasarrufu ne olacaktır?

- Büyükşehir çalışmalarında belediye başkanlarının yetkisi artırtılarak başkanlık modeline geçiş planlanmakta mıdır?

- $\quad$ Üniter yapı ile bağdaşmayacak bir yönetim modeli düşünülmekte midir? 


\section{V.ERAT -Y.ÖZKAYA}

- İl merkezinde yoğunlaşacak yetkinin potansiyel sonuçları konusunda bilimsel verilere dayanılarak il ve ilçe başkanlarının görüşlerine başvurulmuş mudur?

- Büyükşehir ile ilgili tasarısı ne düzeydedir ve ne zaman gündeme gelecektir?

Tasarının detaylarına ilişkin varsayımlara dayanan ve bilgi edinilmek için verilen yedi yazılı soru önergesinin her birisi için bakanlığın vermiş olduğu cevap aynıdır (İçişleri Bakanlığı, 2012b/c/d/e/f/g): "Bakanlığımızca bazı il belediyelerinin büyükşsehir belediyelerine dönüştürülmesine yönelik çalışmalar teknik düzeyde devam etmektedir."

İktidar partisi tasarı meclise gelinceye kadar detaylar hakkında bilgi vermeye yanaşmamıştır. Nitekim MHP grubu adına konuşan Nevzat Korkmaz, büyükşehir tasarısının "bir sır gibi saklandı̆̆ını" dile getirmiştir (TBMM TD, 2012h). Aynı partiden milletvekili olan Emin Haluk Ayhan yakın bir ifadeyle, "büyükşehir belediyesinin hangi türünün, hangi şeklinin uygulayacağını" bilgisini edinemediklerini belirtmiştir (TBMM TD, 20121).Yasa ile ilgili muhalefet partilerinin ortaya attıkları düşüncelere, genel olarak tasarı ile ilgili mecliste yapılan görüşmelere ve yazılı soru önergelerine kaynaklık eden önemli referans noktalarının, İçişleri Bakanlığı'nın yukarıda bahsedilen genelgesinin ve Başbakan'ın miting konuşmaları ve bu bağlamda basına yansıyan haberler olduğu anlaşılmaktadır. Hatta Onuncu Beş Yıllık Plan çalışmaları içinde Yerel Yönetimler İhtisas Komisyonu üyeleri de tasarıyı ancak meclise giderken web sayfasına düştüğünde erişebilmiştir (Toprak, 2016). Bu nedenle 6360 sayılı yasanın neden olduğu birçok değişiklik bu süreç içinde tartışılmamıştır. Buna rağmen yapılan tartışmalar 6360 sayılı yasa tasarısının meclise geldikten sonra zeminini oluşturmuştur.

\section{TASARI MECLISTEYKEN YAPILAN TARTIŞMALAR}

İlk haliyle ismi Büyükşehir Belediyesi Kanunu ile Bazı Kanun ve Kanun Hükmünde Kararnamelerde Değişiklik Yapılmasına Dair Kanun Tasarısı olan 
metin 8 Ekim 2012'de meclis başkanlığına sunulmuştur. Meclis başkanlığı tasarıyı tali komisyon olarak Plan ve Bütçe Komisyonuna, esas komisyon olarak İçişleri Komisyonuna aynı gün havale etmiştir (TBMM TD, 2012i; TBMM TD, 2012j).Tasarı İçişleri Komisyonu'nda görüşülmüş, Plan ve Bütçe Komisyonu'nda görüşülmemiştir. Bu durum daha sonraki tartışmalarda muhalefetin getirmiş olduğu eleştiriler içinde yer almıştır (TBMM TD, 2012n). İçişleri Komisyonu'nun,10 Ekim'de, birinci görüşmesinde tasarı için bir alt komisyon oluşturulmasına karar verilmiştir (TBMM İçişleri Komisyonu, 2012a).

İçişleri Alt Komisyonu; İçişleri, Adalet, Maliye, Ulaştırma, Denizcilik ve Haberleşme, Çevre ve Şehircilik ve Kalkınma Bakanlıkları ile Ankara Üniversitesi Siyasal Bilgiler Fakültesi, TMMOB Ziraat Mühendisleri Odas1, Gazi Üniversitesi Tapu Kadastro Meslek Yüksek Okulu, Çankaya Belediyesi, Devlet Personel Başkanlığı, Türkiye Belediyeler Birliği ve TMMOB Şehir Plancıları Odası temsilcilerinin katılımlarıyla tasarıyı incelemiş ve karara bağlamıştır.

İçişleri Alt Komisyonu'nun hazırladığı raporda tasarı aleyhine getirilen eleştirilerin Türkiye'nin yerel yönetim felsefesiyle doğrudan ilişkili olduğu görülmektedir. (i) tasarının Anayasa'ya aykırı olması, (ii) yerel halkın görüşüne başvurulmaması, (iii) Yatırım İzleme ve Koordinasyon Başkanlığı'nın merkezi idarenin taşra uzantısını işlevsiz hale getireceği ve (iv) yerel yönetimlere uygun bir yönetişim alanı oluşturmayacağı şeklindeki maddeler bunlardan bazılarıdır. Buna karşın tasarı; lehinde belirtilen görüşlere, aleyhte getirilen görüşlere verilen cevaplara ve tasarının yasalaşması halinde kurulacak büyükşehirlerin kazanacağ 1 işlevsellik üzerine yoğunlaşmıştır. Lehte belirtilen görüşlerin bir kısmı şu şekildedir: (i) Nüfusu yüz binin üzerinde olan belediyelerde kadın ve çocuk konuk evlerinin açılması olumlu bir gelişmedir.(ii) Mabetler ve tarihi dokuların korunması önemlidir. (iii) Tasarının ülkede etnik bölünme ve üniter yapıya zarar verecek nitelikte görülmesi yersizdir. (iv) Yatırım İzleme ve Koordinasyon Başkanlığı genel idarenin taşraya götürmek istediği hizmetler ve yatırımlarda öncü olacaktır (TBMM, 2012, s. 39-43). 


\section{V.ERAT -Y.ÖZKAYA}

Raporda öncelikle Büyükşehir Belediyesi Kanunu ile Bazı Kanun ve Kanun Hükmünde Kararnamelerde Değişiklik Yapılmasına Dair Kanun Tasarısı'nın başlığı, "On Üç İlde Büyükşehir Belediyesi ve Yirmi Üç İlçe Kurulması İle Bazı Kanun Ve Kanun Hükmünde Kararnamelerde Değişiklik Yapılmasına Dair Kanun” olarak değiştirildiği belirtilmiştir. Bunun gibi birçok değişiklik yapılmışsa da bunlar genel olarak ibare, isim ve mahalle sınırlarının değiştirilmesi şeklindeki tekniğe ve biçime ilişkin değişikliklerdir. Muhalefetin aleyhte belirttiği öze ilişkin bir değişiklik söz konusu olmamıştır. Raporda muhalefet; hükümet tarafından görüşmeler esnasında verilen 27 önergenin görüşülen metnin bir tasarı değil taslak olduğunu gösterdiği, tasarının Plan ve Bütçe Komisyonu'nda iş yoğunluğu nedeniyle görüşülmediği ve İçişleri Komisyonu'nun görüşmesi için yeterli sürenin verilmediği, tasarının seçim çevrelerini etkileyecek bir seçim kanunu olduğu şeklinde esas, usul ve şekil açısından şerh koymuştur. Genel olarak muhalefet tasarının geri çekilmesini genel olarak şu görüşlere dayanarak savunmuştur: (i) Yönetim yapısı ilden bölgeye kaymaktadır. (ii) Temsili demokrasiyi daraltmaktadır. (iii) Tasarı ölçek ekonomisine yerel halkın hizmet ihtiyacı yerine, işletme iktisadı çerçevesinden bakmaktadır. (iv) Yasalaşması halinde yerel halka mali yük getirecektir. (v) Yerel Yönetimler Özerklik Şartı'na aykırıdır (TBMM, 2012, s. 49-58).

Alt Komisyon'un raporu sunması üzerine İçişleri Komisyonu'nda görüşmeler 14 Ekim'de tekrar başlamış ve sekiz gün sürmüştür. İçişleri Komisyonu görüşmelerine Başkanı ve Mardin Milletvekili Muammer GÜLER başkanlığında; İçişleri, Adalet, Maliye, Enerji ve Tabii Kaynaklar bakanlıkları ile Türkiye İstatistik Kurumu, Emniyet Genel Müdürlüğü, Maden İşleri Genel Müdürlüğü, Devlet Personel Başkanlığı, Yüksek Seçim Kurulu Başkanlığı, Türkiye Şoförler ve Otomobilciler Federasyonu Başkanlığı, Türkiye Belediyeler Birliği, Türkiye Muhtarlar Federasyonu ile Türkiye Muhtarlar Konfederasyonu temsilcileri katılmıştır. Görüşmeler sonunda hazırlanan raporda muhalefet ileri sürdügüu görüşler ve hükümeti temsilen yapılan açıklamalar alt komisyonda yapılan tartışmalarla paralellik arz etmektedir. İktidarın tasarı ile gerçekleştirmek istediği 
yerel yönetim anlayışında bir değişim olmamıştır. Muhalefet İçişleri Alt Komisyonu'nda sayılanlara ek olarak; tasarının Anayasa'ya aykırılığı nedeniyle Anayasa Komisyonu'nda tartışılması gerektiğini, iktidar partisinin tartışma, savunma ve açıklama yapmaktan kaçındığını, tasarının yalnızca hukuksal değil il ve ilçe sınırları üzerinde çalışılmasını gerekli kıldığını ve buna bağlı olarak bilimsel açıdan da sorunlu olduğunu, halkı iki farklı yerel yönetim mevzuatına tabi kılacağından eşitlik ilkesine aykırı olduğunu şerh koyarak ifade etmiştir (TBMM, 2012, s. 49-58).

Komisyon görüşmelerinin başlamasıyla muhalefet partileri tasarıyı özellikle ilgili bölge halkıyla paylaşmış ve içeriğiyle ilgili görüş vermek ve almak için girişimlerde bulunmuştur. CHP'nin; 168'i CHP'li, 152'si AKP'li, 63'ü MHP'li, 22'si DP'li, 8'i BDP'li olan toplamda 430 beldede gerçekleştirdiği referandumlarda oy kullanan 362 bin kişiden 352 bini beldelerinin kapatılmaması yönünde oy kullanmıştır (TBMM TD, 20121; TBMM TD, 2012n). Komisyon görüşmeleri bittikten sonra mecliste 6 Kasım 2012'de görüşülmeye başlanmıştır (TBMM TD, 2012m). Fakat muhalefet partileri zaman zaman büyükşehir yasası ile ilgili düşüncelerini tasarıyı gördükleri için gündeme taşımışlardır. Tasarının yeterince tartışılmadan, paylaşılmadan meclis gündemine getirilmesi ve yeterli zamanın olmayışı öncelikli sorunlar arasında görülmüştür. Nitekim Mehmet Şandır tasarının Meclis Başkanlığı'na gönderildiği gün konu ile ilgili olarak şu cümleleri sarf etmiştir: "Bu Büyükşehir Belediye Yasası'nı kendi milletvekillerinizden bile sakladınız. Bir yıldır konuşuluyor, henüz daha yeni elimize geçti ve hemen Komisyonu toplantrya davet ettiniz, önümüzdeki hafta da Genel Kurula getireceğinizi ifade ediyorsunuz.”(TBMM TD, 2012i; TBMM TD, 2012m). Taslağın hızlı bir şekilde yasalaştırılmak istenmesi ve muhalefet partilerinin yasalaşması halinde büyükşsehirlerde meydana gelebilecek değişiklikler konusundaki eleştirel görüşleri taslağın esas yönünden tartışılmasını sekteye uğratmıştır. İktidar partisi 7 Kasım günü yapılacak görüşmeler sonrasında tasarının yasalaşmasını planlamışsa da bunda muvaffak olunamamıştır. Birinci gün akşam saatinde başlayan görüşmeler muhalefetin komisyon raporlarında dile getirdiği 


\section{V.ERAT -Y.ÖZKAYA}

özellikle usule ilişkin eleştirilere bağlı olarak yoğun tartışmalar ile başlamış günün sonunda bitmiştir (TBMM TD, 2012m).

İkinci gün 14.00'te başlayıp ertesi gün 04.10'a kadar süren görüşmeler, yapılan tartışmalar ve sürekli sataşmalar nedeniyle sağlıklı bir şekilde ilerleyememiştir (TBMM TD, 2012n). Sonraki günlerde de meclis geç saate kadar çalışmış, ${ }^{5}$ muhalefet partileri tasarının Anayasa'nın 2, 3, 10, 90, 123, 126 ve 127 'nci maddelerine aykırı olduğu, tasarının yerel halka sunulacak hizmetlerin etkinliğini arttırmayacağı ve neoliberal politikalara hizmet edeceği, Türkiye'nin yönetim yapısını federal devlet anlayışına yaklaştıracağı ve kentli-köylü ayrımını ortadan kaldırarak kültürel yapıya olumsuz etki edeceği şeklinde birçok eleştiri getirmiştir(TBMM,2012k; TBMM TD, 2012o; TBMM TD, 2012ö; TBMM TD, 2012p; TBMM TD, 2012r). Sonuç olarak, 338 sıra sayılı yasa tasarısı, iki gün İçişleri Alt Komisyonu'nda, dokuz gün İçişleri Komisyonu'nda toplam 118 saatlik bir çalışma ile meclise gelmiştir. Bu süre içinde 366milletvekili söz almış ve 346 önerge verilmiş ve bunların 47'si tasarıda yer edinmiştir. 6 Kasım günü mecliste tartışılmaya başlanan tasarı, 11 Kasım günü başlayan görüşmelerin ertesi gün saat 06.04'te başlayan oturumunda (223 kabul ve 27 ret ile) kabul edilmiştir (TBMM TD, 2012r).

\section{SONUÇ}

Hükümetin, siyasi değerlendirmelerine bağlı olarak büyükşehir sayısını otuza çıkaran ve bu belediyelerde il mülki sınırını büyükşehir belediye sınırı haline getiren 6360 sayılı yasa tasarısı; her ne kadar kaliteli, etkin, verimli vb. iyileştirici gerekçelere dayanılarak ortaya konmuşsa da Türkiye'nin yerel yönetim anlayışında neden olduğu köklü değişimler ve nüfusun \% 83'sini etkileyen yapısı nedeniyle gündeme geldiği zaman siyasi tartışmaların merkezinde yer almış ve pek çok açıdan bilim insanları ve araştırmacılar tarafından incelenmiştir (bknz. Toprak vd., 2016). Birçok alanda özgün sonuçlarının gözlemlenebilmesi için uzun yıllara

58 Kasım günü başlayan görüşmeler ertesi gün 02.36'ya; 9 Kasım günü başlayan görüşmeler 23.33'e; 10 Kasım günü başlayan görüşmeler günün önemi nedeniyle 14.46'ya; 11 Kasım günü başlayan görüşmeler ertesi gün 06.28'e kadar sürmüştür (TBMM TD, 2012o; TBMM TD, 2012ö; TBMM TD, 2012p; TBMM TD, 2012r). 
ihtiyaç duyulan yasa (Sadioğlu vd., 2015: 89) bu çalışmada diğer çalışmalardan farklı olarak kamu politikası süreci arasında yer alan yasalaştırma aşaması açısından ele alınmıştır.

Halkın yerel yönetimlerce uygulanan kamu politikalarında doğrudan ve birincil derecede muhatap olması yerel yönetimleri demokrasinin işlerlik kazandığ 1 öncelikli idari yapılar haline getirmektedir. Bu nedenle demokratik temelde siyaset üreten ülkelerde ulus üstü ya da ulusal politikalar ile karşılaştırıldığında yerel politikalarda, bunların işleyiş sürecinde yer alan özellikle gündeme gelme ve formüle etme aşamasında kamunun kendisinin daha etkili bir aktör olması doğaldır. Müzakereci demokrasi hâkim olmasa da birçok ülkede müzakereci demokrasi araçları (bknz. Demir, 2011, s. 219; Erat ve Kaçer, 2014, s. 5) uygulanmaktadır. Özellikle yerel politikaların neler olduğu, bu politikaların nasıl belirleneceği konusunda halkın katılımı giderek artan bir uygulamadır. Halkın politikaların formüle edilmesi sürecini etkilemesi aynı zamanda yasalaşma sürecini de etkilemesi anlamına gelmektedir. Nitekim her iki aşama literatürde çoğunlukla birlikte anılmaktadır. Oluşturulan politikalarda doğrudan halkın katılımını sağlayacak mekanizmaların bulunmadığ ülkelerde yasalaştırma süreci daha önemli hale gelmektedir. Çünkü halk temsilcileri aracıllğıyla sürece etki etmekte ve parlamentolar muhalefet partilerinin kurucu siyasal iktidarın kararlarına etki edecek önemli mekânlar haline gelmektedir.

Türkiye'de her ne kadar katılımcı demokrasiye yönelik lehte söylemler yaygınlık kazansa da, çoğu kere özellikle de yerel yönetimler açısından slogan değeri taşımaktadır. 6360 sayılı yasanın yasallaşma süreci bu tespitin önemli bir göstergesidir. Yerel halkı doğrudan etkileyen ve uzun vadede bu etkilerin devam edeceği yasanın, gündeme geldiği günden meclise gelinceye kadar geçen süreçte birincil derecede aktör olan muhalefet partilerinin dahi içerik hakkında yeterli bilgiye sahip olmadığı anlaşılmaktadır. Sözlü ve yazılı soru önergeleri şeklinde bilgi alınmaya yönelik çabalar, iktidarın yasanın içeriği vermekten kaçınması nedeniyle sonuç getirmemiştir. Yasa meclise başkanlığına sevk edilmesi ile siyasal partilerin ideolojik tutumları, özerklik bağlamında yerel yönetim algıları ve diğer 


\section{V.ERAT -Y.ÖZKAYA}

öncelikleri temelinde yoğun bir şekilde tartışılmaya başlanmıştır. İçişleri ve İçişleri Alt Komisyonu'nda toplamda 11 gün tartışılan yasa tasarısına yoğun eleştiriler getiren muhalefet partileri biçim ve tekniğe ilişkin konularda etkili olurken; siyasal iktidarın tasarladığı yerel yönetim anlayışında, öze ilişkin, herhangi bir değişime gidilmesini sağlayamamıştır. Kısa süre içinde birçok beldede referanduma giden muhalefet, beldelerinin kapatılmamasını isteyen çoğunluğu gündemde tutarak sürece etki etmek istemişse de başarılı olamamıştır. 6 Kasım 2012'de meclise gelen tasarı iktidar tarafından hemen yasalaştırması planlanırken, muhalefetin engellemeleri ve getirdiği yoğun eleştiriler nedeniyle 12 Kasım'da yasalaşmıştır.

Sonuç olarak getirilen eleştirilerin dayanağı, usul ile ilgili olup, yasalaştırma sürecinin demokratik ilkeleri dikkate alma açısından sağlıklı işlemediğini göstermektedir. Tasarının oluşturulması aşamasında gerek halk gerek siyasal partilerin bilgilendirilmemesi; iktidarın profesyonel ilgi gruplarına bilgi vermekten kaçınması; meclis başkanlığına sunulduktan sonra tasarının Plan ve Bütçe ile Anayasa Komisyonu'nda hiç, İçişleri Komisyonu'nda muhalefetçe yeterli sürenin ayrılmaması; son olarak meclis görüşmelerinde önemli görülen tasarıyı acele yasalaştırma çabası yasalaştırma sürecinin zayıf noktalarını oluşturmaktadır. Ayrıca Avrupa Yerel Yönetimler Özerklik Şartı'nın çekince konulan "Yerel makamları doğrudan ilgilendiren tüm konulara ilişkin planlama ve karar alma süreçleri içinde, kendileriyle olanaklar ölçüsünde zamanında ve uygun biçimde danışılacaktır." 4/6. maddesi hükümetin elini güçlendirmiş ve bu durum 6360 sayılı yasanın yasalaştırma sürecince ortaya çıkmıştır. Öte yandan Şartın Özerk Yerel Yönetimin Kapsamını ortaya koyan "Yerel yönetimlerin sinırlarında, mevzuatın elverdiği durumlarda ve mümkünse bir referandum yoluyla ilgili yerel topluluklara önceden danışılmadan değişiklik yapılamaz (md. 5)." hükmü çekince konulmamasına rağmen göz ardı edilmiştir. Ayrıca, 6360 sayılı yasanın yasalaştırma sürecinde, Yerel Özerklik Şartı'nın öngördüğü doğrultuda, üniversitelerin, kamu kurumu niteliğindeki meslek kuruluşlarının, sivil toplum örgütleri ve diğer kuruluşların görüşlerine başvurulduğuna dair yeterli bilgi de yoktur. Kuşkusuz, yeteri derecede kamuoyu baskısı olmadığı için 6360 sayılı 
yasanının çıkarılma sürecinde demokratikleşme ve katılım mekanizmaları oluşturulamamıştır. Daha da önemlisi, böylesine kısa sürede yasalaştırılan ve çok ciddi sonuçları olan 6360 sayılı yasa ve belki de bunun gibi birçok yasa önceden hazırlanmış ve halkın önüne zamanla sunulmuş aslında birer yasallaştırma politikasının ürünüdür.

\section{KAYNAKÇA}

AĞBABA, V. (2012), Yazılı Soru Önergesi, http://www2.tbmm.gov.tr/d24/7/77482s.pdf, (27.07.2016).

AK Parti (2011), 27 Mayıs Muğla Mitingi Konuşmasının Tam Metni, http://www.akparti.org.tr/site/haberler/27-mayis-mugla-mitingi-konusmasinintam-metni/8135\#1, (25.07.2016).

AKDOĞAN, A. A. (2011), "Türkiye'de Kamu Politikası Disiplinin Tarihsel İzleri”, Türkiye'de Kamu Yönetimi ve Kamu Politikaları, (Ed. Kartal, F.), TODAİE, Ankara, 76-98.

AKGÜL, A. ve KAPTI, A. (2010), Türkiye'nin Uyuşturucu ile Mücadele Politikası: Politika Süreç Analizi, Ankara Polis Akademisi Yayınları, 75-99.

AKOVA, A.N. (2012), Yaz1lı Soru Önergesi, http://www2.tbmm.gov.tr/d24/7/74559s.pdf, (27.07.2016).

ARAP, İ.ve ERAT, V. (2015), "Bir Kamu Politikasının Analizi: Türkiye'de Geçici Köy Koruculuğu”, Mülkiye Dergisi, 39(4), 73-108.

ARIKBOĞA, E. (2015), "Büyükşsehir Belediye Meclisleri Yapısı ve İşleyişi”, Yerel Demokrasi Sorunsalı, (Der. Semerci, P. U.), Bilgi Yayınları, İstanbul, 4973.

BİRİKLAND, T. A. (2011), An Introdiction to the Policy Process, M. E. Sharpe. 


\section{V.ERAT -Y.ÖZKAYA}

BİRKLAND, T. A. (2005), "Models of the Policy Process", J Rabin, Encyclopedia of Public Administration and Public Policy, Taylor \& Francis Group, Boca Raton, 188-191.

BÜYÜKATAMAN, İ. (2012), Yaz11 $\quad$ Soru Önergesi, http://www2.tbmm.gov.tr/d24/7/7-6127s.pdf, (27.07.2016).

ÇELİKYAY, H. (2014), Değişen Kent Yönetimi ve 6360 Sayılı Büyükşehir Yasas1, SETA Analiz, 101.

ÇEVIK, H. H. DEMİRCİ, S. (2012), Kamu Politikası, Seçkin Yayıncılık, 2. Baskı, Ankara.

DEMİR, F. (2011), "Kamu Politikası Sürecinde Müzakerenin Rolü ve Sürecin Demokratikleşmesi”, Kamu Politikası Süreci (Ed. Alican Kaptı), Seçkin Yayınc1lık, Ankara, 205-236.

DYE, T. R. (1987), Understanding Public Policy, Prentice Hall, New Jersey.

ERAT, V. KAÇER, F. (2014), "Siyasa Yapım Sürecinde Müzakereci Yaklaşımlar", Adnan Menderes Üniversitesi Sosyal Bilimler Enstitüsü Dergisi, $1(4), 57-75$

GÜL, H. BATMAN, S. (2013), "Dünya ve Türkiye Örneklerinde Metropoliten Alan Yönetim Modelleri ve 6360 Sayılı Yasa", Yerel Politikalar, Ocak-Haziran Say1s1, 7-47.

HAVUTÇA, N. (2012), Yazılı Soru Önergesi, http://www2.tbmm.gov.tr/d24/7/75277s.pdf, (27.07.2016).

HOWLETT M. ve RAMESH M. (1995), Studying Public Policy: Policy Cycles and Policy Subsystems, Oxford University Press, New York.

İÇIŞLERİ BAKANLIĞI (2012a), Altan Tan'ın Yazılı Soru Önergesine Cevap, http://www2.tbmm.gov.tr/d24/7/7-3828sgc.pdf, (27.07.2016). 
İÇIŞLERİ BAKANLIĞI (2012b), Ayşe Nedret Akova'nın Yazılı Soru Önergesine Cevap, http://www2.tbmm.gov.tr/d24/7/7-4559c.pdf, (27.07.2016).

İÇIŞLERİ BAKANLIĞI (2012c), Namık Havutça'nın Yazılı Soru Önergesine Cevap, http://www2.tbmm.gov.tr/d24/7/7-5277sgc.pdf, (27.07.2016).

İÇIŞLERİ BAKANLIĞI (2012d), İsmet Büyükataman'ın Yazılı Soru Önergesine Cevap, http://www2.tbmm.gov.tr/d24/7/7-6127sgc.pdf.pdf, (27.07.2016).

İÇIŞLERİ BAKANLIĞI (2012e), Veli Ağbaba'nın Yazılı Soru Önergesine Cevap, http://www2.tbmm.gov.tr/d24/7/7-7482sgc.pdf, (27.07.2016).

İÇİ̧̧LERİ BAKANLIĞI (2012f), Umut Oran'ın Yazılı Soru Önergesine Cevap, http://www2.tbmm.gov.tr/d24/7/7-7708c.pdf, (27.07.2016).

İÇİ̧LERİ BAKANLIĞI (2012g), Hasan Ören'nin Yazılı Soru Önergesine Cevap, http://www2.tbmm.gov.tr/d24/7/7-8898c.pdf, (27.07.2016).

JANN, Werner - WEGRICH, Kai (2007), "Theories of thePolicy Cycle", (Ed. Fischer, Frank, M., Gerald J. ve Sidney, M. S.), Handbook of PublicPolicy Analysis, CRC Prss: Boca Raton, 43-62.

KAPTI, A. (2016), "Kamu Politikası Süreci”, Kamu Politikaları Ansiklopedisi, (Ed. Altunok, H ve Gedikkaya, F. G.), Nobel Yayınları, Ankara, 152-154.

KAPTI, A. (Ed.) (2013), "Kamu Politika Sürecinde Klasik Yaklaşım Modeli”, Kamu Politikası Süreci, Seçkin Yayıncılık: Ankara, 2013.

ORAN, U. (2012), Yaz1l1 Soru Önergesi, http://www2.tbmm.gov.tr/d24/7/77708s.pdf, (27.07.2016).

ÖREN, H. (2012), Yaz1l1 Soru Önergesi, http://www2.tbmm.gov.tr/d24/7/78898s.pdf, (27.07.2016). 


\section{V.ERAT -Y.ÖZKAYA}

PARLAK, B. ve Ökmen, M. (2015), Yerel Yönetimler, Kuram ve Uygulamada Küresel ve Ulusal Konular ve Sorunlar, Ekin Basın Yayın Dağıtım, İstanbul.

SABATIER, P. A. (2007), Theories of the Policy Process, Westview Press, Colorado.

SADİĞLU, U. ÖZACIT, İ. ve ÖMÜRGÖNÜLŞEN U. (2015), "Yeni Büyükşehir Belediyesi Modeli: Türkiye'de Değişen/Değişmeyen Merkezileşme ve Adem-i Merkezileşme Politikaları”, Yasama Dergisi, 30, 70-92.

TAN, Altan (2012), Yaz1l1 Soru Önergesi, http://www2.tbmm.gov.tr/d24/7/73828s.pdf, (27.07.2016).

TBMM İÇIŞLERİ KOMİSYONU (2012a), 24. Yasama Dönemi, 3. Yasama Y11.

TBMM TD (2011a), 6. Birleşim, 24. Dönem, 1. Cilt, 1. Yasama Yı11.

TBMM TD (2011b), 17. Birleşim, 24. Dönem, 4. Cilt, 2. Yasama Yılı.

TBMM TD (2011c),18. Birleşim, 24. Dönem, 4. Cilt, 2. Yasama Yı1ı.

TBMM TD (2011d), 38. Birleşim, 24. Dönem, 9. Cilt, 2. Yasama Y111.

TBMM TD (2011e), 39. Birleşim, 24. Dönem, 9. Cilt, 2. Yasama Yıll.

TBMM TD (2011f), 13. Birleşim, 24. Dönem, 3. Cilt, 2. Yasama Y1lı.

TBMM TD (2011g), 33. Birleşim, 24. Dönem, 8. Cilt, 2. Yasama Yılı.

TBMM TD (2011h), 20. Birleşim, 24. Dönem, 4. Cilt, 2. Yasama Yılı.

TBMM TD (2012a), 46. Birleşim, 24. Dönem,10. Cilt, 2. Yasama Y11.

TBMM TD (2012b), 100. Birleşim, 24. Dönem,20. Cilt, 2. Yasama Yı11. 
TBMM TD (2012c), 47. Birleşim, 24. Dönem, 10. Cilt, 2. Yasama Y1lı.

TBMM TD (2012d), 48. Birleşim, 24. Dönem, 10. Cilt, 2. Yasama Y1lı.

TBMM TD (2012e), 116. Birleşim, 24. Dönem, 22. Cilt, 2. Yasama Y1lı.

TBMM TD (2012f), 120. Birleşim, 24. Dönem, 23. Cilt, 2. Yasama Y11.

TBMM TD (2012g), 79. Birleşim, 24. Dönem, 16. Cilt, 2. Yasama Y1lı.

TBMM TD (2012h), 123. Birleşim, 24. Dönem, 24. Cilt, 2. Yasama Y1lı.

TBMM TD (20121), 126. Birleşim, 24. Dönem, 25. Cilt, 2. Yasama Yı11.

TBMM TD (2012i), 5. Birleşim, 24. Dönem, 2. Cilt, 3. Yasama Y1lı.

TBMM TD (2012j), 6. Birleşim, 24. Dönem, 30. Cilt, 3. Yasama Y1lı.

TBMM TD (2012k), 7. Birleşim, 24. Dönem, 2. Cilt, 3. Yasama Y111.

TBMM TD (20121), 10. Birleşim, 24. Dönem, 31. Cilt, 3. Yasama Yı11.

TBMM TD (2012m), 16. Birleşim, 24. Dönem, 4. Cilt, 3. Yasama Yı11.

TBMM TD (2012n), 17. Birleşim, 24. Dönem, 32. Cilt, 3. Yasama Y1lı.

TBMM TD (2012o), 18. Birleşim, 24. Dönem, 5. Cilt, 3. Yasama Y1lı.

TBMM TD (2012ö), 19. Birleşim, 24. Dönem, 5. Cilt, 3. Yasama Y11ı.

TBMM TD (2012p), 20. Birleşim, 24. Dönem, 5. Cilt, 3. Yasama Y1lı. 


\section{V.ERAT -Y.ÖZKAYA}

TBMM TD (2012r), 21. Birleşim, 24. Dönem, 5. Cilt, 3. Yasama Y1l1.

TOPRAK, Z., ÖZER, Y. E., YONTAR, İ. G. ve Tenikler, G. (Ed.) (2016), Büyükşehir Yönetimi ve İl Yönetiminin Yeni Yüzü, KAYSEM 10 Bildiriler Kitab1, 5-7 Mayıs 2016, İzmir.

TOPRAK, Z. (2014), Yerel Yönetimler, Siyasal Kitabevi, Ankara.

TOPRAK, Z. (2016), Yüz yüze yapılan görüşme notları. İzmir

TÜRKIYE BELEDIYELER BİRLİ̆́̆. http://www.tbb.gov.tr/belediyelerimiz/istatistikler/genel-istatistikler/, (01.08.2016).

YAYED (2012a), 24 Nisan 2012 Tarih ve 11085 Sayılı İçişleri Bakanlığ Genelgesi Üzerine YAYED Görüşü, http://www.yayed.org/id217-yayedgorusu/yayed-gorusu.php, (01.08.2016).

YAYED (2012b), 24 Nisan 2012 Tarihli Büyükşehir Genelgesine Yürütmeyi Durdurma Karar1 (27 Kasim 2012), http://www.yayed.org/id293-haberduyuru/24-nisan-2012-tarihli-buyuksehir-genelgesine-yurutmeyi-durdurmakarari-27-kasim-2012.php, (01.08.2016).

YILDIZ, M. ve SOBACI, M. Z. (Der), (2013), "Kamu Politikası ve Kamu Politikası Analizi: Genel Bir Çerçeve", Kamu Politikası Kuram ve Uygulama, Adres Yayınları, Ankara. 